University of Rhode Island

DigitalCommons@URI

Open Access Master's Theses

1977

\title{
Self-Esteem and Leadership in Physical Education Among Senior High School Girls
}

Gail B. Bender

University of Rhode Island

Follow this and additional works at: https://digitalcommons.uri.edu/theses

\section{Recommended Citation}

Bender, Gail B., "Self-Esteem and Leadership in Physical Education Among Senior High School Girls" (1977). Open Access Master's Theses. Paper 1758.

https://digitalcommons.uri.edu/theses/1758

This Thesis is brought to you for free and open access by DigitalCommons@URI. It has been accepted for inclusion in Open Access Master's Theses by an authorized administrator of DigitalCommons@URI. For more information, please contact digitalcommons-group@uri.edu. 
SELF-ESTEEM AND LEADERSHIP IN PHYSICAL EDUCATION AMONG

SENIOR HIGH SCHOOL GIRIS

BY

GAIL B. BENDER

A THESIS SUBMITTED IN PARTIAL FULFILLMENT OF THE REQUIREMENTS FOR THE DEGREE OF

MASTER OF SCIENCE

IN

PHYSICAL EDUCATION

UNIVERSITY OF RHODE ISLAND

1977 


\section{ABSTRACT}

The purpose of this study was to determine the differences between self-esteem ratings and positions of leadership. in physical education among three groups of senior high school girls. It was thought that there would be significant differences in ratings of self-esteem among girls in selected positions of leadership, appointed positions of leadership, and no leadership positions. The following hypotheses were tested:

1. There will be a significant difference between selfesteem ratings of those girls selected to a position of leadership in physical education and those appointed to a position of leadership.

2. There will be a significant difference between selfesteem ratings of those girls appointed to a position of leadership in physical education and those who are in no position of leadership.

3. There will be a significant difference between selfesteem ratings of those girls selected to a position of leadership in physical education and those who are in no position of leadership.

Through a sociogram administered to students enrolled in regular physical education classes, the selected group of leaders $(\mathrm{N}=30)$ and those in no position of leadership $(\mathrm{N}=30)$ 
were determined. The girls who were currently participating in a leadership corp $(\mathrm{N}=30)$ were selected as the group representing those who were deemed serving in a position of appointed leadership.

Once the girls were grouped according to leadership positions, the subjects were administered a self-esteem rating scale to determine if any differences existed. Rosenberg's self-esteem scale was used to determine the ratings. Additionally, to determine whether there were any physical skill differences between the groups of leaders and non-leaders, a volleyball skills pre-test was also employed. The skill test data were used primarily for informational purposes. Following all testing, the scores for the self-esteem test for each group and the volleyball pre-skills test were placed in tabular form and group means were found. Once means were determined, a one-way analysis of variance was employed to determine if any of the groups differed significantly at the usual level of significance $(.05)$.

Results of the analyses indicated that there were no significant differences within the self-esteem ratings between the three groups studied. Each of the three hypotheses was therefore rejected. As for the difference in skill between the selected group of leaders and those in no position of leadership, it was shown that those selected to a position of leadership by their classmates had a significantly higher level of skill than the non-leaders. 
TABLE OF CONTENTS

CHAPTER

PAGE

I

INTRODUCTION.

Statement of the Problem. . . . . . . . 1

Limitations of the Study........ . . . . 2

Justification for the study . . . . . . . 2

Definition of Terms . . . . . . . . . 4

II REVIEW OF LITERATURE. • . • . . . . . . . . 6

Literature and Research Pertaining to

Physical and Psychological Characteristics of Leaders.....

Literature and Research Pertaining to

the Influences of Situational Factors

on Leadership Role . . . . . . . . 12

III PROCEDURES IN RESEARCH. . . . . . . . . . . 14

Source of Data. . . . . . . . . . . 14

Collection of Data... . . . . . . . 16

Instruments Used: . . . . . . . . . 16

Administration of Rosenberg Test. . . 17

Analysis of Data.......... . 17

iV ANALYSis OF DATA . . . . . . . . . . . 19

Analysis of Self-Esteem Ratings . . . . 19

Analysis ot Skills Test. . . . . . . . 21

V SUMMARY, CONCLUSIONS, AND RECOMMENDATIONS . 23

Summary . . . . . . . . . . . . . 23

Conclusions and Discussion... . . . . 24

Major Recommendations . . . . . . . 26

REFERENCES. . . . . . . . . . . . . . . . . . . 27

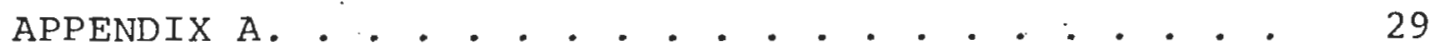

APPENDIX B. . . . . . . . . . . . . . . . . . . . . 30 


\section{LIST OF TABLES}

TABLE

PAGE

I Means, Standard Devisions of Three Groups on Self Esteem Ratings. . . . . . . . . . 19

II ANOVA-Self-Esteem Ratings . . . . . . . . 20

III Means, Standard Deviations of Volleybail Skill Test. . . . . . . . . . . . . . 21

IV ANOVA-Skill Test. . ........... 21 
CHAPTER I

INTRODUCTION 


\section{INTRODUCTION}

Many studies have been undertaken pertaining to personal characteristics of individuals deemed as leaders. This study examined the psychological trait of self-esteem in reference to three different groups of senior high school girls currently enrolled in physical education.

\section{Statement of the Problem}

The purpose of this study was to determine the differences between self-esteem ratings and positions of leadership. in physical education among three groups of senior high school girls. The three groups studied included those girls selected to a position of leadership in physical education, those appointed to a position of leadership, and those who were in no position of leadership.

The following hypotheses were tested:

1. There will be a significant difference between selfesteem ratings of those girls selected to a position of leadership and those appointed to a position of leadership.

2. There will be a significant difference between selfesteem. ratings of those girls appointed to a position of leadership in physical education and those who are in no position of leadership. 
3. There will be a significant difference between selfesteem ratings of those girls selected to a position of leadership and those who are in no position of leadership.

Limitations of the Study

The study was limited in the following respects:

1. The only subjects studied were girls, in grades 9, 10, and 11, located at one high school in the state of Rhode Island.

2. The study reflected leadership rating as applied to only one unit of physical activity, namely, volleyball. This is an important limitation since it has been fairly well established that in addition to physical, intellectuaj, and personality traits of leaders, the situational context of the leadership role is equally important in determining leadership potential.

3. Since validity coefficients have not been obtained, it is assumed that the scores on the Rosenberg self-esteem scale accurately measure self-esteem.

Justification for the study

If favorable results are to occur within the fields of physical education it is necessary to understand the underlying psychological and sociological contributions that can be made by the physical education profession. The physical education teacher is constantly involved with individuals who can 
lead a group. Numerous activities require the selection of team captains and many teachers employ the use of student leaders to assist in instruction. In dealing with the area of leadership, it seems important that certain personality traits should be studied to better understand the characteristics of individuals deemed leaders as well as the leadership potential in an individual.

The researcher became involved with studying the personal characteristics of leaders while taking a graduate course in research. After doing a report for the course on assessing leadership potential from certain personality and psychological traits of an individual, the researcher found that many studies have specifically related personality characteristics such as aggressiveness (Jennings), dominance (Parten), intelligence (Nelson), and self-confidence to leadership. Most of the studies suggested that leaders rate higher than non-. leaders in self-confidence. Zeleney (27) reported that student leaders rated higher in self-confidence than non-leaders according to a rating scale devised to rate leaders on certain personality traits. Richardson and Hanawalt (21), using the Bernreuter Inventory, studied both men and women college leaders and found that the leaders were more self-confident than the non-leaders or than the norms. Richardson and Hanawalt (22) also studied adult executive leadership and tested two types of leaders, a) supervisors and office holders, and b) non-supervisors and non-office holders. Using the Bernreuter Personality Inventory, the researchers found office 
holders to be more self-confident than non-office holders or than the norm for adult men. Supervisors were found to be more self-confident than non-supervisors. Since self-confidence is closely related to self-esteem in that both traits imply a certain faith in oneself, a question that could be raised is whether the results would provide the same information if testing the trait of self-esteem. The researcher contends that the trait of self-esteem is worth studying because according to Rosenberg (23), an individual between the age of fifteen and eighteen is very concerned with his/her self-image. Therefore, it was felt that this would be a good age group to study. If it can be demonstrated that there are significant differences between positions of leadership and self-esteem ratings, the physical education teacher may be better able to ascertain who will emerge as leaders.

The researcher is not trying to develop self-esteem through leadership but rather is conducting a study to see if those deemed as leaders rate higher in self-esteem ratings than those deemed as non-leaders.

This study therefore contributes both to the physical education profession as physical educators are constantly aware of leadership potential, and to the psychological aspect of one personality - the self-esteem.

Definition of Terms

1. Leadership - The act of leading, to direct the operations, 
activity, or performance of; to have charge of; to guide someone or something along a way $(25: 479)$.

2. Appointed leader - Those students appointed to a position of leadership by the teacher.

3. Selected leader - Those students elected to a position of leadership by their peers.

4. Non-leader - Those students not appointed and/or elected to positions of leadership.

5. Self-esteem - The degree to which an individual respects himself and considers himself worthy, although he recognizes his limitations and expects to grow and improve $(16: 745)$. 6. Physical Education - Refers to the public school instructional program. It does not refer to interscholastic athletics or intramurals.

7. Self-confidence - Confidence in oneself and in one's powers and abilities $(25: 783)$.

8. Self-image - One's conception of oneself or of one's role $(25: 784)$. 
CHAPTER II

REVIEW OF LITERATURE 
REVIEW OF LITERATURE

litoraturo within tho area of leadership has substantiated that leadership potential of an individual is essentially a combination of personality traits and the particular situation in which the leadership role occurs (zeigler). Therefore, the purpose of this review is to report some of the literature and research findings pertaining to: (1) Physical and psychological characteristics of leaders; and (2) the influences of situational factors on leadership roles.

Literature and Research Pertaining to Physical and Psychological Characteristics of Leaders

Most of the investigations within the area of leadership and personality were completed prior to 1960 . Hunter and Jordan (12) investigated the qualities and characteristics - associated with leadership in a southern state university by analyzing those traits possessed by recognized leaders. These investigators found that leaders were younger than non-leaders, non-leaders were heavier than leaders, there was a slight tendency for leaders to be taller, leaders were higher in intelligence and received higher grades on courses, and the leaders were more dominant in face-to-face situations. According to Flemming (6), the traits that correlated the highest 
with leadership were lively, amusing, intelligent, wide interests, pleasant voice, good sport, not modest, and athletic. To see if there was a difference in personality factors between leaders and non-leaders, Nelson (17) studied members of high school basketball teams. The results involved with intelligence and height and weight indicated that both the leaders and non-leaders were above the normal range in intelligence. As to height and weight, the leaders were slightly shorter, but heavier in stature than the non-leaders. Hemphill (11), when studying the results of a questionnaire administered to five hundred respondents above the age of eighteen, found that when the respondents compared leaders to other members, the leaders were taller, older, more intelligent, and larger. Parten (19), who observed thirty-four children in nursery school for onerminute intervals, found that leaders were higher in intelligence than non-leaders, and that leadership developed with the increase of school years as independent play subsided in frequency with the advance of age. Nutting (18) utilized a nominating procedure whereby girls listed their reasons for the selection of certain individuals as captains of their gymnasium teams. The characteristics of these captains were: they were slightly above average in intelligence, age, physical ability, noticeably above average in popularity and slightly below average in scholarship. Caldwell and Wellman (3) found that athletic captains and assistant captains ranked low in mental age and $I . Q$. but fairly 
high in scholarship when studying seven characteristics of leaders in six types of school activities. Additionally, the girls were ranked as extroverts in all types of leadership except those involved in athletics. The athletic leaders wẹre ranked at balance between extroversion and introversion. The boys tended to be more extrovertive, but not to such a marked degree as the girls $(3: 13)$.

According to most of the studies and literature reviewed on the relationship between intelligence and leadership, it was found that leaders tend to be more intelligent than those they lead. Breckenridge and Vincent (1), found that children who possessed obvious ability and prestige seemed to sustain the role of leadership, as, in peer groups or highly organized play, leadership is affected by intelligence, 'school marks, social status and age. It has also been reported that average children chose moderately superior children to lead more of ten than extremely superior children. Along these same lines Gouldner (8) reported that among findings of researchers there is a definite relationship between the leader's intelligence and the average intelligence of the group. First of all, the leader has higher intelligence than the average in the group and secondly, the superiority of intelligence which the leader possesses has an effect on whether he will obtain or hold onto that leadership. If it is superior to a great degree, he may lose or never obtain that leadership. Related to this is the following from Murphy, Murphy, and Newcomb (15). "Children 
who are too superior in age and abilities are not accepted as leaders. For instance, children with intelligence quotients of 150 are more likely to be leaders in a group of children with intelligence quotients in the neighborhood of 130 to 1140 than in a group of children with average intelligence" (15:525). When Brown (2) studied 259 high school pupil leaders who were chosen by their fellow students for positions of leadership, comparisons were made between pupils of different degrees of leadership instead of leaders and non-leaders. It was observed that the leaders exceeded the average of the school as a whole in intelligence and $90 \%$ of the leaders entered institutions of higher learning as compared to $67 \%$ of all graduates. Hunter and Jordan (12) reported that the vast majority of studies disclosed that intelligence is a definite part of leadership.

Stogdill (24), when surveying the literature, revealed a discrepancy on the correlations between height and leadership in the many studies he reviewed. He reported that the general trend of these studies is to indicate a low positive relationship betweon height and leadership, the average correlation being about .30 (24:41). Cratty (4), when referring to three studies (Gowin, Baldwin and Levin, and Hunter and Jordan), stated that height has a slight positive correlation with assuming a leadership role and individuals of normal height tend to look up to taller men as leaders. Along with other qualities, therefore, height appears to be a social asset 
positively correlated with status and leadership (4:12). In looking back at previous findings, Hunter and Jordan (12) recognized a slight tendency for leaders to be taller, as did Hemphill (11). On the other hand according to Nelson (17), leaders were shorter.

Stogdill (24) also reported a low positive relationship between weight and leadership, after correlating several of the studies done in this area. Cratty (4) reported that in a camp for "normal" youngsters where fighting was not frequent, there was a high correlation between weight, size, age, and status. But in a camp for "disturbed" youth where fighting was frequent, the high correlations were not found. Thus because there was so much direct physical conflict and toughness for dominance in the camp for "disturbed" youth, status was not based on age, weight, and size.

In the camp for normal children, whose opportunity for the direct outlet of hostility corresponded more with conditions in the adult community, perceived ability to dominate another could be based only upon the cues available; namely, size, age, and height. These findings might, therefore, explain the tendency for adult leaders to have more stature and to be heavier than their followers. It appears that for securing a leadership role an adult's perceived capacity for action via stature is a more important determinant than direct physical action, which is hardiy ever seen $(4: 53)$.

Nelson (17) reported that leaders were heavier in stature than non-leaders, Hemphill (11) that leaders were larger, but Hunter and Jordan (12) reported that the non-leaders were heavier. 
Richardson and Hanawalt (9) completed a study of 258 businessmen divided into two groups - office holders and supervisors, and non-office holders and non-supervisors. The Bernreuter Personality Inventory was used to compare their scores against the norms. It was found that office holders and supervisors were more dominant than the control groups and norms. It was also found that they were less neurotic, less introverted, more self-confident, and more self-sufficient than the control groups and norms.

In relation to dominating others in the acquiring of leadership, Parten (19) found that in the nursery school children, leadership emerged on two grounds; that of artfully and diplomatically directing the group and that of using brute force and personal power to dominate others. Gibb (7) suggested that according to research done involving the relationship of dominance to leadership, there is no substantiation of the dependance of leadership upon dominance need. Cratty (4) and Pigors $(20: 9)$ stated that young children of ten dominate one another, until the age of ten when full-fledged leadership appears in a heterogeneous group.

In summary then, research has fairly well substantiated that intelligence has been found to be a big positive factor in identifying the characteristics of a leader. However, there is a big discrepancy and conflicting research in the traits of height, size or age where different studies yielded different results. In addition to these findings, based upon the review of literature though, the following traits appear 
to be identified with those individuals deemed as leaders: lively, amusing, wide interests, pleasant voice, good sport, not modest, athletic, physical ability, above average in popularity, less neurotic, more self-confident and more selfsufficient.

Literature and Research Pertaining to the Influence of Situational Factors on Leadership Role

Several studies support the view that leadership depends upon the situational aspect. Gibb (7) stated that the choice of a specific individual for the leadership role will be more dependent upon the nature of the group and of its purpose than upon the personality of the individual. Jenkins. (14) after reviewing leadership studies reported that the individual who becomes the leader of a given group engaging in a particular activity and what the leadership characteristics are in a given case are a function of the specific situation and that there are wide variations in the characteristics of individuais who become leaders in similar situations and even a greater divergence in leadership behavior in different situations. Hemphill (11) suggested that the best way to study leadership is to combine both the trait approach and the situational approach. He contended that a definition of leadership must include both the characteristics of a social. situation and the characteristics of an individual. According to Feidler (5) it is futile to distinguish leaders from. 
followers on the basis of personality traits. Knowledge and skill of the group task distinguishes a leader from his coworker. Zeigler and Spaeth (26) stated that the situational approach evolved as researchers who were searching for universal leadership traits discovered instances when the characteristics of leaders varied from one situation to another. Thus, this approach has now taken precedence $(26: 86)$. It can therefore be seen that the situational context of the leadership role is an important consideration in determining leadership potential. 
CHAPTER III

PROCEDURES IN RESEARCH 


\section{III}

\section{PROCEDURES IN RESEARCH}

\section{Source of Data}

The purpose of this study was to determine the differences between self-esteem ratings and positions of leadership among three groups of senior high school girls in grades nine eleven. The three groups studied, all students from a suburban Rhode Island High School, included the following: a) thirty girls appointed to positions of leadership by their teacher; b) thirty girls selected by their peers to a position of leadership within the physical education class; and c) a random sample of thirty girls holding no position of leadership within the physical education class, selected proportionately at random from each class.

In order to do any testing, the principal of the school was first contacted. He gave his consent with the understanding that the name of the school would not be used. Then, with the assistance of the two women physical education teachers, the following research was carried out.

First, the physical education teacher who worked with and was the adviser of the girls leadership corps was consulted and was asked to choose approximately sixty girls from grades 9, 10, and 11 proportionately with a degree of knowledge and skill in volleyball to compose the group of appointed 
leaders. From the list of sixty, thirty girls were selected at random to comprise the appointed leader group. Second, a sociogram (see Appendix A) was administered to each student within each physical education class. This included four ninth grade classes, four tenth grade classes; and three eleventh grade classes. This was given to discern the group of leaders selected by their peers to a position of leadership within the physical class and the group of girls holding no position of leadership within the physical education class. The sociogram was administered by the researcher at the start of the regular physical education class. On the sociogram the names of all the students in the class were listed and the student was asked "whose team would you most like to be on?" listing five girls in order of preference. They were instructed to think in terms of volleyball teams. From this listing, the top four girls chosen from each class constituted the group of selected leaders. Of this group of forty-four names, it was later narrowed down to thirty after checking with the other list of appointed leaders to make sure a girl was not on two lists. Also, some may have transferred schools or classes or not have completed the skills test to follow. The group of thirty girls holding no position of leadership were randomly selected from the sociogram as every sixth girl who was not on any other list.

Next, to determine the skill levels of each student prior to the instructional unit of volleyball to see if any differences were evident, a volleyball skills pre-test was 
administered to each physical education class. This was done at the start of the regular physical education class by both the physical education teacher and the researcher.

Collection of Data

Instruments used

To collect data regarding self-esteem ratings, Rosenberg's self-esteem scale (21) was employed. According to Hellison (9) this instrument possesses the advantages of ease of administration and scoring, economy of time, several measures of validity and high reproducibility and scalibility coefficients. According to Rosenberg (23) a study by Silber and Tippett reported a test-retest reliability of .85 . for this instrument.

The scale is a ten item test that has the respondent answer whether he/she strongly agrees, agrees, disagrees, or strongly disagrees with questions on self-esteem. However, instead of scoring the test on a 0-high esteem to 6-low esteem basis, the researcher scored each of the ten questions on a 1-high esteem to 4-low esteem basis. Each answer was scored with a number from 1-4. Then all the ten numbers were added to produce a total score for each individual. The test is contained in Appendix B.

To test for beginning volleyball skills, each student was administered a one-minute consecutive wall volley with emphasis on keeping the ball above a line 6 feet from the 
floor and standing behind a line 2 feet away from the wall. The students were paired with a partner and told to count the consecutive hits the partner made within a one-minute time limit. The scores obtained for each student were determined by the number of consecutive hits made within the time limit.

Administration of the Rosenberg test

Once the girls were grouped according to leadership positions, each subject was administered the Rosenberg. Inventory. This was done during an activity period so that all the girls could take the test at once. The subjects were instructed to write their locker number on the test paper. The test administrator could then discern the three groups by corresponding their locker number to their name. No time limit was set for the completion of the test. The testing took approximately 15 minutes for the girls to complete.

\section{Analysis of data}

Upon completion of all testing, the data were subjected to statistical analysis. To analyze the self-esteem ratings, the means, standard deviations, and standard errors of the means were first computed for each group. To test hypotheses I, II, and III, a one-way analysis of variance for uncorrelated means was used. Significant differences were tested at the .05 level of significance. 
To study the possible influences that volleyball skill may have had on selection of students for position of leadership, the means, standard deviations and standard error of the means were computed from the volleyball pre-skills test. Analysis of variance was used and significant differences were tested at the .05 level of significance. 
CHAPTER IV

ANALYSIS OF DATA 


\section{ANALYSIS OF DATA}

This chapter contains (1) an analysis of the data pertaining to the self-esteem ratings of the three groups of leaders, and (2) an analysis of the volleyball skills test employed to study the differences between the groups of leaders and non-leaders.

\section{Analysis of Self-Esteem Ratings}

To determine if significant differences between the three groups were evident, the means, standard deviations, and standard errors of the means were first established. Table I reports the statistics.

\section{TABLE I}

Means, Standard Devisions of Three Groups on Self-Esteem Ratings

\begin{tabular}{|c|c|c|c|}
\hline & $\ddot{x}$ & $S D$ & $\mathrm{SEm}$ \\
\hline $\begin{array}{l}\text { Elected leaders } \\
\qquad \mathrm{N}=30\end{array}$ & 22.20 & 2.74 & .50 \\
\hline $\begin{array}{l}\text { Leaders club } \\
\qquad N=30\end{array}$ & 22.67 & 4.10 & .75 \\
\hline $\begin{array}{c}\text { Non-leaders } \\
\mathrm{N}=30\end{array}$ & 22.03 & 3.67 & .67 \\
\hline
\end{tabular}


Table I reports the means, standard deviations, and standard errors of the means of the three groups regarding selfesteem ratings. Since the total score for the 10 item scale ranged from 10 (high self-esteem) to 40 (low self-esteem), it was determined by the researcher that a score of 25 would indicate a neutral rating. As indicated in Table I each of the three group means were found to be within the range of what the researcher considered neutral.

To test hypotheses I, II and III, data were then subjected to a one-way analysis of variance for uncorrelated means. Table II reports the results of this analysis.

TABLE II

ANOVA - Self-Esteem Ratings

Source of Variation

$d f$

SS

MS

$S D$

F

Among Means

2

12

6.00

Within Groups

87

1135

89

1.147

13.05

3.61

.46

Table II indicates that an $F$ ratio of .46 was obtained. To reach significance at the .05 level of confidence, with 2/87 degrees of freedom, an $F$ ratio of 3.10 was needed. The obtained $\mathrm{F}$ ratio was therefore not significant at the necessary level, thereby indicating that there were no significant differences between the means of the three groups. Hypotheses I, II, and III were therefore rejected. There were no 
significant differences of self-esteem ratings between the three groups studied.

\section{Skill Analysis}

To study the possible influence physical skill of students might have had on selection of students for positions of leadership, students were administered a volleyball skills test. The descriptive data are shown in Table III.

\section{TABLE III}

Means, Standard Deviations of Volleyball Skill Test

\begin{tabular}{lccc}
\hline GROUP & $\mathrm{X}$ & $\mathrm{SD}$ & $\mathrm{SEm}$ \\
Elected Leaders & 19.45 & 11.58 & 2.15 \\
Non-Leaders & 13.43 & 8.33 & 1.52 \\
\hline
\end{tabular}

To determine if the difference between the means of elected leaders and non-leaders were statistically significant, the data were analyzed by analysis of variance. Table IV reports the results of this analysis.

TABLE IV

ANOVA-SKILI TEST

\begin{tabular}{lrrrrrr}
\hline Source of Variation & df & SS & MS & SD & F \\
Among Means & 1 & 533 & 533 & & \\
Within Groups & 57 & 5970 & 104.7 & 10.23 & 5.09 * \\
\hline
\end{tabular}

*Indicates significance beyond .05 level of significance. 
As indicated in Table IV; an F ratio of 5.09 . was found and this was significant beyond the .05 level of significance. The data therefore indicate that those students who were selected by their classmates to a position of leadership demonstrated a significantly greater degree of volleyball skill than did those girls who were not elected to a position of leadership. 
CHAPTER V

SUMMARY, CONCLUSIONS, AND RECOMMENDATIONS 
SUMMARY, CONCLUSIONS, AND RECOMMENDATIONS.

\section{Summary}

Rosenberg's self-esteem scale was administered to ninety high school girls representing three groups: (a) thirty girls appointed to a position of leadership; (b) thirty girls selected to a position of leadership; and (c) thirty girls in no leadership position. The following three hypotheses were tested: (1) There will be a significant difference between self-esteem ratings of those girls selected to a position of leadership and those appointed to a position of leadership; (2) there will be a significant difference between selfesteem ratings of those girls appointed to a position of leadership in physical education and those who are in no position of leadership; and (3) there will be a significant difference between self-esteem ratings of those girls selected to a position of leadership and those who are in no position of leadership. As a result of the analysis of the data all three hypotheses were rejccted. The data indicated that: (1) there were no significant differences in the self-esteem ratings of both appointed and selected leaders and non-leaders; and (2) there was no significant difference in the self-esteem ratings between those selected to lead and those appointed to lead. Additionally, it was found that the group of selected leaders 
demonstrated a' significantly greater degree of volleyball skill $(p<.05)$ than did those girls who were in no position of leadership.

\section{Conclusions and Discussion}

Based upon the results of this study, it can be stated that within the context and limitations of the study the following conclusions are evident:

1. No significant differences were observed between the levels of self-esteem of girls either appointed or selected as leaders and those who were in no position of leadership. Despite this observation, however, it is important to recognize that these results were obtained during the involvement of the subjects during only one physical activity; namely, volleyball. It has been fairly well established by previous research (zeigler) that leadership potential is essentially dependent upon both the presence of certain personality characteristics and the particular leadership situation.' This factor could undoubtedly be an important contributing factor influencing the results of the study. Therefore, to project inferences beyond the limitations of this study would be extremely dangerous. It could very well be that the level of an individual's self-esteem is an important and identifiable characteristic in determining leadership potential among girls in positions of leadership in other settings and physical activities. 
2. Each of the three groups of women scored on what the researcher considered a neutral level on the Self-Esteem Scale. It was interesting to note that the mean self-esteem scores for each of the three groups were almost identical and fell midway between a high and low self-esteem category rating .

3. It is also interesting to note that previous research within the area of leadership trait identification has indicated the presence of self-confidence as an important and observable personality characteristic of leaders. Since this study was unable to identify self-esteem differences among groups of girls, the findings of the study suggest further that the trait of self-esteem may indeed be an isolated construct of an individual's personality and therefore exist independently from the trait of self-confidence.

4. The presence of physical skill appears to be a viable influence in the selection of leaders in physical education. As indicated in this study, the group of girls who were elected by their classmates to positions of leadership demonstrated a significantly greater degree of volleyball skill than did those who were not involved in leadership roles. This finding supports previous research which has isolated physical skill as an identifiable trait of leaders (Flemming, Nutting) . 
Major Recommendations

Based upon the results and conclusions drawn from this study, the following recommendations are advanced:

1. That a similar study be done in this area specifically in terms of analyzing the trait of self-esteem within a variety of individual, dual, and team sport situations.

2. That the study recommended in Recommendation 1 include a variety of samples drawn from junior high school and college students and the study additionally analyze differences as they may occur within sub-groups.

3. That further research be done to more accurately and concisely identify the variable of self-esteem.

4. That more research be completed in an attempt to measure relationships between physical education teachers' perceptions of leadership potential and precise instrumentation of leadership characteristics. 
REFERENCES 


\section{REFERENCES}

1. Breckenridge, Marian Edgar, and Vincent, Elizabeth Lee. Child Development. Physical and Psychological Growth Through Adolescence. Philadelphia: W.B. Saunders Co., 1965.

2. Brown, Marion. "Leadership Among High School Pupils." Teachers College Record. January, 1934, 35, pp 324-326.

3. Caldwell, O.W. and Wellman, B. "Characteristics of School Leaders." J.Educ. Res. , 1926, 14. pp 1-3.

4. Cratty, Bryant J. Social Dimensions of Physical Activity. New Jersey: Prentice Hall, 1967.

5. Feidler, F.E. "Style or Circumstance: The Leadership Engima." Psychology Today, 1969, 2, p. 38-43.

6. Flemming, Edwin G. "A Factor Analysis of the Personality of High School Leaders." J. Appl. Psychol., 1935, 39 , pp 596-605.

7. Gibb, C.A. "The Principles and Traits of Leadership." J. Abn. and Soc. Psychol., 1947, 42, pp. 267-284.

8. Gouldner, A. (ed.). Studies in Leadership. New York: Harper and Brothers, 1950 .

9. Hanawalt, N.G. and Richardson, H.M. "Leadership as Related to the Bernreuter Personality Measures: IV. An Item Analysis of Responses of Adult Leaders and Non-Leaders." J. of Appl. Psych.., Oct. 1944, pp 39741. 1 .

10. Hellison, Donald R. "Physical Education and the SelfAttitude." Quest., 1970, XIII, pp. 41-45.

11. Hemphill, John K. Situational Factors in Leadership. Ohio: Bureau of Educational Research, Ohio State University, 1949 .

12. Hunter, E.C. and Jordan, A.M: "An Analysis of Qualities Associated with Leadership Among College Students." J. Educ. Psych. , 1939, 30, 497-509.

13. Jennings, Eugene E. An Anatomy of Leadership. New York: Harper and Brothers, 1960 . 
14. Jenkins, W.D. "A Review of Leadership Studies with Particular. Reference to Military Problems." Ṕsychology Bulletin, 1947, 44, pp 54-79.

15. Murphy, G., Murphy, L., and Newcomb, T. Experimental Social Psychology. New York: 1937.

16. Neale, Daniel, Sonstroem, Robert, and Metz, Kenneth. "Physical Fitness, Self-Esteem, and Attitudes Toward Physical Activity:" Research Quarterly, December, 1969,40 , pp 743-749.

17. Nelson, Dale 0. "Leadership in Sports." Research Quarterly, May 1966, pp. 268-275.

18. Nutting, R. L. "Some Characteristics of Leadership." School and Society, 1923, 18, pp. 387-9.0.

19. Parten, Mildred B. "Leadership Among Preschool Children." J. Abnorm. and Soc. Psych., 1933, 27, pp 430-440.

20. Pigors, P.: "Leadership and Domination Among Children." . Sociology, 1933, p. 9.

21. Richardson, H.M. and Hanawalt, N.G. "Leadership as Related to Bernreuter Personality Measures: I. College Leadership in Extra-curricular Activities. J. Soc. Psych., 1943, 17, pp 237-249.

22. Richardson, H.M. and Hanawalt, N.G. "Leadership as Related to Bernreuter Personality Measures: III. Leadership Among Adult. Men in Vocational and Social Activities." I. App1... Psych., 1944, 28, pp 308-317.

23. Rosenberg, Morris. Society and the Adolescent SelfImage. Princeton, N.J.: Princeton University Press, $1965, p-16-18$.

24. Stogdill, Ralph N. "Personal Factors Associated With Leadership: A Survey of the Literature." J. of Psych., 1948, 25, pp 35-7.1.

25. Webster's Seventh New Collegiate Dictionary. G. and C. Merriam Co., Springfield, Mass., 1961.

26. Zeigler, Earle F. and Spaeth, Marcia J. (ed.). Administrative Theory and Practice in Physical Education and Athletics, New Jersey, Prentice-Hall, Inc., 1975.

27. Zeleny, Leslie Day. "Characteristics of Group Leaders." Sociology and Social Research, Vol. 24, 1939-40, pp 140-149. 
APPENDICES 


\section{APPENDIX A}

\section{SOCIOGRAM}

The subjects were administered the sociogram in the gymnasium at the beginning of their regular physical education class. The researcher passed out a paper to each girl containing a list of students in the class with the following directions:

$$
\begin{aligned}
& \text { "Whose team would you most like to be on? List five } \\
& \text { girls in order of preference." }
\end{aligned}
$$

The subjects were told to think in terms of volleyball and who they might want as their captains.

List of students in the class 
APPENDIX B

ROSENBERG'S SELF-ESTEEM TEST

Please circle the correct response. Do not write your name. Put your gym basket number here

1. On the whole, I am satisfied with myself.

Strongly, agree Agree Disagree Strongly disagree

2. At times I think I am no good at all.

Strongly agree Agree Disagree Strongly disagree

3. I feel that I have a number of good qualities.

Strongly agree Agree Disagree Strongly disagree

4. I am able to do things as well as most other people. Strongly agree Agree D Disagree Strongly disagree

5. I feel I do not have much to be proud of. Strongly agree Agree Disagree Strongly disagree

6. I certainly feel useless at times. Strongly agree. Agree Disagree Strongly disagree

7. I feel that $I$ am a person of worth, at least on an equal plane with others.

Strongly:agree Agree Disagree STrongly disagree

8. I wish I could have more respect for myself.

Strongly agree Agree Disagree Strongly disagree

9. All in all, I am inclined to feel that I am a failure.

Strongly agree Agree Disagree Strongly disagree

10. I take a positive attitude toward myself.

Strongly agree Agree Disagree Strongly disagree 